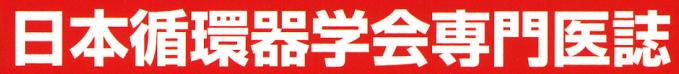

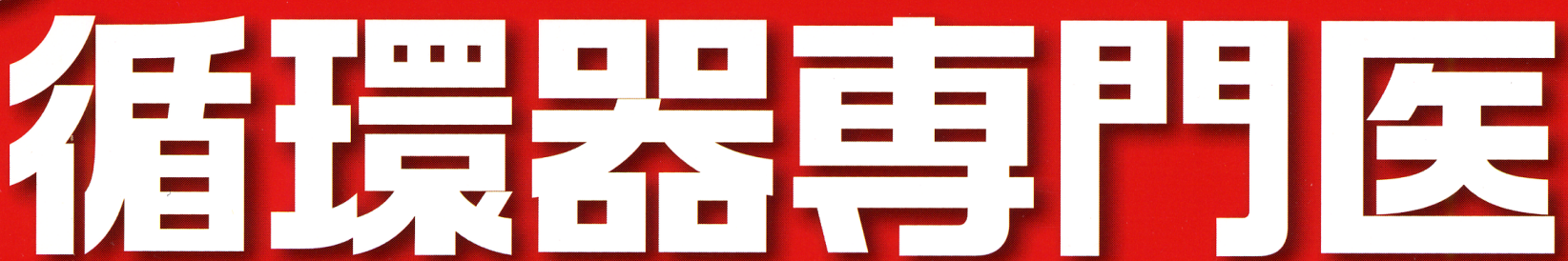

\section{Journal of JCS Cardiologists}

Vol.23 No.1 2015

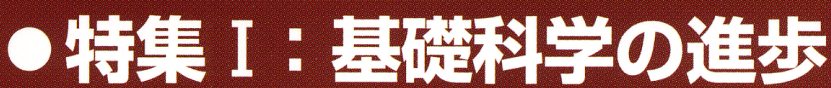

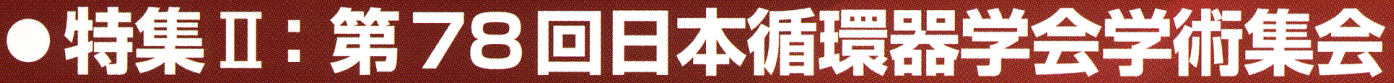

\section{○循環器举2014年の進紫}

小児循環器学・ 心電学・心臓病学・心不全·高血圧

口症例検討

ロ専門医トレーニング問題

ロ日本で発見された疾患概念：冠攣縮性狭心症一一概念の成立と展開

口循環器專門医活動と現況

口循環器病專門施設見学

口学会印象記

口専門医NEWS/循環器專門医研修施設，研修関連施設／学術集会日程 